"Investor perception of fair value evaluation: focusing on financial instruments"

\begin{tabular}{|c|c|c|}
\hline AUTHORS & \multicolumn{2}{|c|}{ Minjung Kang iD https://orcid.org/0000-0001-9835-0567 } \\
\hline ARTICLE INFO & \multicolumn{2}{|c|}{$\begin{array}{l}\text { Minjung Kang and Young-Tae Yoo (2019). Investor perception of fair value } \\
\text { evaluation: focusing on financial instruments. Investment Management and } \\
\text { Financial Innovations, 16(1), 203-214. doi:10.21511/imfi.16(1).2019.16 }\end{array}$} \\
\hline DOI & \multicolumn{2}{|c|}{ http://dx.doi.org/10.21511/imfi.16(1).2019.16 } \\
\hline RELEASED ON & \multicolumn{2}{|l|}{ Monday, 11 March 2019} \\
\hline RECEIVED ON & \multicolumn{2}{|l|}{ Thursday, 31 January 2019} \\
\hline ACCEPTED ON & \multicolumn{2}{|l|}{ Monday, 25 February 2019} \\
\hline & \multicolumn{2}{|l|}{$(\mathrm{cc}) \mathrm{EY}$} \\
\hline LICENSE & \multicolumn{2}{|c|}{$\begin{array}{l}\text { This work is licensed under a Creative Commons Attribution } 4.0 \text { International } \\
\text { License }\end{array}$} \\
\hline JOURNAL & \multicolumn{2}{|c|}{ "Investment Management and Financial Innovations" } \\
\hline ISSN PRINT & \multicolumn{2}{|l|}{$1810-4967$} \\
\hline ISSN ONLINE & \multicolumn{2}{|l|}{$1812-9358$} \\
\hline PUBLISHER & \multicolumn{2}{|c|}{ LLC "Consulting Publishing Company "Business Perspectives" } \\
\hline FOUNDER & \multicolumn{2}{|c|}{ LLC "Consulting Publishing Company "Business Perspectives" } \\
\hline & & E: \\
\hline NUMBER OF REFERENCES & NUMBER OF FIGURES & NUMBER OF TABLES \\
\hline 28 & 0 & 4 \\
\hline
\end{tabular}

(C) The author(s) 2023. This publication is an open access article. 


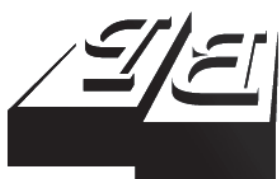

BUSINESS PERSPECTIVES

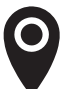

LLC "CPC "Business Perspectives" Hryhorii Skovoroda lane, 10, Sumy, 40022, Ukraine

www.businessperspectives.org

Received on: $31^{\text {st }}$ of January, 2019 Accepted on: 25 th of February, 2019

(C) Minjung Kang, Young-Tae Yoo, 2019

Minjung Kang, Assistant Professor, Incheon National University, Incheon, South Korea.

Young-Tae Yoo, Assistant Professor, Incheon National University, Incheon, South Korea.

\section{(ㄷ) (i)}

This is an Open Access article, distributed under the terms of the Creative Commons Attribution 4.0 International license, which permits unrestricted re-use, distribution, and reproduction in any medium, provided the original work is properly cited.

\title{
INVESTOR PERCEPTION OF FAIR VALUE EVALUATION: FOCUSING ON FINANCIAL INSTRUMENTS
}

\begin{abstract}
This study analyzed capital market investors' recognition of the predictability of fair value-based valuation. It was examined if market investors overvalue the predictive value of fair value by comparing that value with that measured in accounting performance. The results reveal that investors are likely to overvalue fair value more than predictive values reflected in accounting performance. In particular, the results show that investors can gain abnormal returns through the market anomaly due to the functional fixation that investors cannot distinguish between unrealized profits and realized ones. Though there are considerable studies about accrual anomaly, few studies explore it with the separation of unrealized profits from total accruals. A number of studies about the causes of accrual anomaly have been conducted from various perspectives. The analysis of this study argues that the unrealized profits derived from fair value evaluation can be a cause of accrual anomaly. On the basis of the result, this study suggests that information about unrealized earnings should be reported separately.
\end{abstract}

\section{Keywords}

JEL Classification

\section{INTRODUCTION}

This study analyzed market investors' perception of the predictability of fair value-based valuation. We determined that market investors tend to overvalue the predictive value of fair value by comparing that value with that measured in reality in accounting.

The application of fair value accounting keeps expanding for the purpose of financial accounting, which is the provision of useful information in predicting future corporate performance. The theoretical definition of fair value implies that it is helpful in the prediction of future performance. However, its usefulness is considerably controversial concerning reliability of measurement and inadequate application. The inadequate application of fair value measurement was addressed as a reason for the global financial crisis of 2008. Critics also called attention to several problems of fair value accounting such as the financial accelerator phenomenon ${ }^{1}$ caused by fair value and the selective measurement of financial instruments with no market prices.

It can be important to analyze whether fair value accounting can satisfy the purpose of its introduction rather than historical cost measurement in spite of its lower reliability. Previous studies, however, have mainly examined value relevance of fair value under the assumption

1 Barth and Landsman (2010) indicate this around the banking business as the phenomenon of financial accelerator with a medium of fair value evaluation. That is, if the property value fluctuates along with business fluctuations, the profit of a financial institution and net worth's fluctuations cause the fluctuation of asset management scale, which results in the expansion of economic fluctuation by the fair value evaluation. 
of market efficiency. That is, a number of studies have identified whether the valuation price based on fair value measurement is reflected in the stock price (e.g., Bernard \& Ruland, 1987; Barth, 1991; Easton et al., 1993; Barth et al., 1996; Barth \& Clinch, 1998).

This study identifies investors' understanding of the predictability of the fair value measurements. The predictive values of fair value in accounting and the value perceived by market investors are compared. Specifically, Sloan (1996) reports an accrual anomaly where investors tend to overvalue the predictive values of accruals compared to their realities. By separating accruals into unrealized accruals by fair value evaluation and realized ones, this study analyzes the accrual anomaly of fair value gains and losses.

We adopt the methods of Kraft et al. (2007) developed from Sloan's (1996) methods, which conducted Mishkin (1983) verification, using listed firms in the Korean stock market from 2011 to 2012. The results of the analysis reveal that investors tend to overvalue fair value more than predictive values reflected in accounting performance. In particular, the results show that investors can gain abnormal returns through the market anomaly characterized by the overvaluation of unrealized profits. It can be interpreted that investors tend to overvalue unrealized profits due to the functional fixation that investors cannot distinguish between unrealized profits and realized ones.

This study makes several unique contributions to the literature. We identified that investors tend to overvalue the predictive value of fair value by comparing that value with that measured in reality in accounting performance. Though there are considerable studies (Sloan, 1996; Xie, 2001, etc.) about accrual anomaly, there are few studies that explore it with the separation of unrealized profits from total accruals. A number of studies about the causes of accrual anomaly (Xie, 2001; Chen \& Cheng, 2002; Richardson et al., 2005, etc.) have been conducted from various perspectives. As the extension study of accrual anomaly, this study argues that the unrealized profits derived from fair value measurement can be a cause of accrual anomaly. Under the accounting circumstances where the unrealized profits keep increasing, and the statements of comprehensive income including the unrealized profit are reported as the main information in financial statements, this analysis will contribute to the recognition of investors' understanding of this situation.

The rest of this study is organized as follows. Section 1 provides the related literature and presents our hypotheses. Section 2 describes our research design and the sample selection. Section 3 discusses our results and findings. Finally, conclusions and implications are provided in the last section.

\section{RELATED LITERATURE AND HYPOTHESES}

\subsection{Literature on fair value measurement}

With the expansive application of fair value accounting, prior studies explored whether the fair value evaluation has larger incremental information contents than the historical cost evaluation. Concerning the value relevance of fair value, no significant associations were found until the 1980s. Only Bernard and Ruland (1987) reported that any significant results concerning value relevance were found in cer- tain industries. As assets, which are evaluated on the basis of their fair values, keep increasing, researchers investigated value relevance for each account since 1990, and most research (Barth, 1991; Easton et al., 1993; Barth et al., 1996; Barth \& Clinch, 1998, etc.) reported that there is significant value relevance. Due to the problem of the reliability of fair value measurements, however, the significant results of value relevance with fair value gains and losses of some investment stocks has not been reported (Barth, 1994; Petroni \& Wahlen, 1995). In Korea, studies about the value relevance of fair value information have been conducted since the early 2000s. They report that information on fair value measurements has value relevance. 
Recent studies concentrate on the reasons why the information on fair value measurements has value relevance, and some studies begin to explore whether information on fair value has an incremental explanatory power as forward-looking information required for the purpose of financial reporting ${ }^{2}$. However, the number of these studies is very small.

For a representative example, Park et al. (1999) analyzed the association between evaluated gains of available-for-sale securities and their future profits. However, they failed to find any significant association between them.

Analyzing British firms, Aboody et al. (1999) proved that the revaluation surplus of fixed assets has positive associations with future operating revenue and cash flow from operation. They made a contribution in that it provided direct evidence that supports reevaluation as more useful for investors than historical cost, under the circumstance in which there are debates about the effectiveness of the reevaluation of fixed assets.

Evans, Hodder, and Hopkins (2014) proved that information about the fair values of interest-bearing investment securities is useful in forecasting interest profit, disposal profit, and cash generation ability. Their research is meaningful in that it directly proved that the fair value of financial instruments has significant predictability in forecasting the profits and cash flows of financial instruments.

\subsection{Literature on accrual anomaly}

Sloan (1996) is the first study that analyzed the difference between predictive value by investors and predictability observed in accounting performance. By dividing net income into accruals and cash flow from operating, he found that investors tend to overvalue the predictability for accruals. Though the real predictability for accruals is lower than the cash flow of operating, investors tend not to understand the difference in the predictability of profit components accurately due to their functional fixation. For that reason, these differences are not reflected accurately in stock prices, and thereby investors tend to overvalue the predictability for accruals. He calls this the "accrual anomaly". Many research- ers (Xie, 2001; Chen \& Cheng, 2002; Richardson et al., 2005, etc.) have analyzed the causes of the accrual anomaly. Distinguishing between discretionary accruals and non-discretionary accruals, Xie (2001) argues that the accrual anomaly is caused by the former. Chen and Cheng (2002) classify discretionary accruals into two groups: one formed by the opportunistic motives of CEOs and the other formed by a company's signal motive to convey its private information to the market. In their research based on this classification of discretionary accruals, they found that there is no difference between these two motives in the production of the accrual anomaly. By dividing accruals into those with high reliability and those with low reliability, Richardson et al. (2005) found that the predictability reflected in accounting performance is lower when reliability is small due to the arbitrary judgments and estimations of CEOs; however, it is reflected in the stock price insufficiently.

Some studies (Thomas \& Zhang, 2002; Chan et al., 2006 , etc.) argue that accrual anomaly is caused by investors' misrecognition of the signals of future corporate performance concerning accruals. As a result, various causes suggested by previous studies can be interpreted as being derived from inadequate information processing by which investors cannot recognize accrual accurately.

Together with a group of studies about operating activities-related accrual anomaly, another stream of studies about accrual anomaly related to dirty surplus (DS) or other comprehensive income recently began to be conducted. For example, Landsman et al. (2011) divide the DS, which belongs to other comprehensive income, into two categories: one is the DS related to fair value measurement and the really dirty surplus (RDS) related to merger by pooling of interests and stock options. They report that both DS and RDS have no significant associations with future accounting performance. On the contrary, in an analysis of investors' responses in the market, they found that investors tend to undervalue RDS; this result implies that investors can get an abnormal return. Contrary to prior studies, we divide accruals into unrealized profits and realized profits generated by fair value evaluation of accruals.

2 The purpose of financial statements in a financial accounting concept system is to provide information for future prediction that is useful or the decisions made by investors and creditors (FASB, 2010). 


\subsection{Hypothesis development}

The predictability of fair value can be different from the predictability that investors expect for the following reasons.

First, fair value measurement is unrealized profits and losses. Thus, their realization as cash flow is uncertain. Fair value gains and losses can be recognized with an assets-liabilities revenue recognition approach $^{3}$, and not the previous realization standards of the past GAAP 4 . Accordingly, the feasibility of turning fair value gains and losses into cash flows will be lower than accruals generated by the previous revenue recognition criteria. When securities and tangible and intangible assets are evaluated by their fair values, it is impossible for investors to forecast the time for realization, because the CEO decides the asset disposal time discretionally. Thus, we anticipate that investors tend to overvalue the predictability of fair value gains and losses due to the uncertainty of their convertibility.

Second, the problem of reliability, which is raised from the opposite perspective of fair value accounting (Hodder et al., 2006; Allen \& Carletti, 2008; Hilton \& O'Brien, 2009; Dechow et al., 2010, etc.), is expected to generate accrual anomaly. Dividing accruals into those with higher reliability and those with lower reliability, Richardson et al. (2005) report that accrual anomaly increases in the case of the latter. It is reported that the recognition of fair value has a large influence on earnings management (Dechow et al., 2010), because the subjective decisions of CEOs increase in choosing measurement methods or evaluation input elements. The problem of the verifiability of measurement can be settled when the measurement is based on market values. However, Hodder et al. (2006) and Allen and Carletti (2008) argue that market price volatility accelerates the volatili- ty of the asset value or profit of a company, because market price volatility is fully reflected in profits. Furthermore, they also demonstrate that the market value has an intrinsic measurement error, and thus the evaluation information hardly reflects economic reality when it is evaluated on the basis of short-term price volatility or with the uncertainty of the market.

Third, the functional fixation by which investors cannot distinguish between unrealized profits and realized ones is considered as a cause of accrual anomaly. The functional fixation, which Sloan (1996) demonstrates as a cause of accrual anomaly ${ }^{5}$, may occur in fair value gains and losses. Unrealized gains and losses are accounted in the distinction between two types according to the degree of realization possibility: one is the type that is recognized as net income ${ }^{6}$, the other is the type that is recognized as other comprehensive income. The first types of unrealized gains and losses are reported by GAAP as net income, because these have a larger convertibility into realized income. These gains and losses have lower convertibility into future cash flow or future income than accruals recognized by realization principles. However, due to the functional fixation where investors cannot recognize net income by item, it is expected that investors will overvalue the predictability of fair value with a low convertibility.

Gains and losses for available-for-sale securities and for derivatives are representative cases that are recognized as other comprehensive income. These types of accruals have a problem of dual recognition in that, at first, a rise after the adjustment of those accruals is recognized as comprehensive gains and losses, and it is recognized again as net income. Thus, if investors fully understood reclassification adjustment accounting, they would adequately evaluate the unrealized fair value gains and losses recognized as other comprehensive income. However, they do not have

3 In the revenue recognition principle of assets and liabilities, when profit increases or liabilities decrease by the increase of economic benefit, we should recognize profits when a benefit's inflow possibility is high regardless of vesting standard. Additionally, it does not differentiate gains from profit, and requires reporting of an all-inclusive income statement as the main financial statement.

4 The previous generally accepted accounting standard of Korea shows the realization criterion for the revenue recognition. Revenue could be recognized when the following two conditions are fulfilled: (1) realization criterion: could be realized or was realized already, (2) vesting condition (occurrence requisite): the process of vesting should be completed. That means there is a qualification for obtaining profits by completing economic duties related to the process of acquiring profit. Therefore, unrealized profit by fair value evaluation cannot be recognized before 2003, or the gains and profit by intercompany unrealized profit should be separated.

5 Sloan (1996) provided the market's unusual phenomenon by accruals and cash flow for the first time. He argued that because of investors functional fixation on accounting information, they could not fully reflect the characteristics of accruals and cash flow in future stock prices. Specifically, he reported that the accruals seemed to be over-estimated; thus, the more accruals a company has, the lower the consistency, and future stock prices were over-estimated.

6 As examples of gains and losses for net income, there are trading securities valuation gain and loss, bad debt expense, gain and loss on translation of foreign currency, etc. 
enough understanding about that. So, they tend to overvalue those.

Fourth, the IFRS demands that companies evaluate their performance in terms of comprehensive income, which includes the unrealized fair value gains and losses. However, investors could not fully understand what it means. IFRS No. 1 stipulates that companies include statements of comprehensive income in the body of their financial statements, but investors could not understand the importance of these statements. Considering this problem, an official from the Korea Exchange said, "Investors need to check footnotes in the statements of comprehensive income, because detailed information about elements of these statements are there". In addition, the official recommends the consideration of the total comprehensive income components, because even though they do not affect net income in the current period, those components can affect future net income or retained earnings. When fair value gains and losses are reported as other comprehensive income, if investors traditionally evaluate corporate performance only with net income standards, fair value gains and losses included in other comprehensive income would be undervalued. Accordingly, we suggest the following hypothesis:

Hypothesis: $\quad$ The real predictability of fair value is different from the predictability that investors reflect in stock prices.

\section{RESEARCH DESIGN AND DATA}

\subsection{Research design}

With the verification of the hypothesis, we analyze the difference between predictive value expected by investors and the degree to which fair value gains and losses affect future performance.

Regarding research methods, we adopt the methods of Kraft et al. (2007) developed from Sloan's (1996) methods. Sloan (1996) conducted Mishkin (1983) verification ${ }^{7}$. However, the methods received the criticism that they may produce distorted results due to a few companies that extremely exaggerate their performances, and they also have omitted a correlated variable problem (Kraft et al. 2007). Accordingly, we added several control variables in Model (1) and Model (2).

The prior study does not distinguish accruals into realized part and unrealized parts by fair value measurement. In contrast, we distinguished accruals as such, and revised the model of Sloan (1996) as follows:

$$
\begin{aligned}
& E A R_{-} N I_{t+1}=\alpha_{0}+\alpha_{1} A C C R_{t}+ \\
& +\alpha_{2} C F O_{t}+\alpha_{3} F V_{t}+\varepsilon_{t} . \\
& C A R_{t+1}=\beta_{0}+\beta_{1} \cdot\left(E A R_{-} N I_{t+1}-\alpha_{0}^{*}-\right. \\
& \left.-\alpha_{1}^{*} A C C R_{t}-\alpha_{2}^{*} C F O_{t}-\alpha_{3}^{*} F V_{t}\right)+v_{t} .
\end{aligned}
$$

$$
\begin{aligned}
& C A R_{t+1}=\beta_{0}+\beta_{1} \cdot\left(\alpha_{0}+\alpha_{1} A C C R_{t}+\right. \\
& +\alpha_{2} C F O_{t}+\alpha_{3} F V_{t}-\alpha_{0}^{*}-\alpha_{1}^{*} A C C R_{t}- \\
& \left.-\alpha_{2}^{*} C F O_{t}-\alpha_{3}^{*} F V_{t}\right)+v_{t} .
\end{aligned}
$$

$$
\begin{aligned}
& C A R_{t+1}=\beta_{0}+\beta_{1} \cdot\left(\alpha_{0}-\alpha_{0}^{*}\right)+ \\
& +\beta_{1} \cdot\left(\alpha_{1}-\alpha_{1}^{*}\right) A C C R_{t}+ \\
& +\beta_{1} \cdot\left(\alpha_{2}-\alpha_{2}^{*}\right) C F O_{t}+ \\
& +\beta_{1} \cdot\left(\alpha_{3}-\alpha_{3}^{*}\right) F V_{t}+v_{t} .
\end{aligned}
$$

7 Accrual anomaly is verified on the basis of the following equation in Sloan (1996).

$$
\begin{aligned}
& \text { Earnings }_{i t+1}=\alpha_{0}+\alpha_{1} C F O_{i t}+\alpha_{2} T A_{i t}+\varepsilon_{i t} . \\
& A R_{i t+1}=\beta_{0}+\beta_{1}\left(\text { Earnings }_{t+1}-\alpha_{0}^{*}-\alpha_{1}^{*} C F O_{i t}-\alpha_{2}^{*} T A_{i t}\right)+v_{i t} .
\end{aligned}
$$

Here, Earnings $=$ net income in $t+1 /$ total assets, $\mathrm{AR}=$ accumulatively calculated size adjusted return between $\mathrm{t}+1$ previous April and $\mathrm{t}+2$ March (constructing 10 portfolios according to the size of aggregate value of listed stock at $t+1$ the end of March), CFO = cash flow generated from operating activities during $\mathrm{t}$ period/total assets, $\mathrm{TA}=$ accruals during $\mathrm{t}$ period/total assets.

(A) Refer to profit prediction that can be used to expect predictability about next profit and loss, such as CFO and TA. Through equation (B), the degree to which CFO and TA at this term contribute to the prediction of future profit is measured for the dependent variable of market rate of return. In equation (B), $\alpha_{1}^{*}$ refers to the degree to which investors expect future profits. If $\alpha_{1}$ and $\alpha_{2}$ in equation (A) are the same as the values of $\alpha_{1}^{*}$ and $\alpha_{2}^{*}$ respectively, it means that the market is efficient. Previous research found that investors tend to undervalue the predictability of cash flow, whereas they overvalue accruals (Xie, 2001, etc.). 


$$
\begin{aligned}
& E A R_{-} N_{t+1}=\beta_{0}+\beta_{1} A C C R_{t}+\beta_{2} C F O_{t}+ \\
& +\beta_{3} F V 1(\text { or } F V 2)_{t}+\beta_{4} S_{Z I E}+\beta_{5} M B_{t}+ \\
& +\beta_{6} L E V_{t}+\beta_{7} V O L_{t}+\Sigma Y E A R_{t}+\Sigma I N D_{t}+\varepsilon_{t} . \\
& C A R_{t+1}=\beta_{0}+\beta_{1} A C C R_{t}+\beta_{2} C F O_{t}+ \\
& +\beta_{3} F V 1(\text { or } F V 2)_{t}+\beta_{4} S_{Z I Z E_{t}}+\beta_{5} M B_{t}+ \\
& +\beta_{6} L E V_{t}+\beta_{7} V O L_{t}+\Sigma Y E A R_{t}+\Sigma I N D_{t}+\varepsilon_{t} .
\end{aligned}
$$

where EAR_NI - net income divided by average assets, $C \bar{A} R$ - size-adjusted abnormal returns accumulated over 12 months from April in year $t+1$ to March in year $t+2, F V 1$ - fair value gain and loss of financial instruments divided by average assets, $F V 2$ - fair value gain and loss excluding impairment loss of financial instruments divided by average assets, $A C C R$ - (net income - operating cash flow- unrealized gain and loss from fair value measurement of financial instruments)/average assets, $C F O$ - operating cash flow divided by average assets, SIZE - natural $\log$ of total sales, $M B$ - market value divided by book value, $L E V$ - total liabilities divided by total equity, $V O L$ - standard deviation of daily stock return

The way to draw Model (2) is the same as that of Kraft et al. (2007). In Model (d), $\beta_{1} \cdot\left(\alpha_{3}-\alpha_{3}^{*}\right)$ would have significant negative value in the case of $\alpha_{3}<\alpha_{3}^{*}$. That is, if $\beta_{3}$, the regression coefficient of $F V$, has significant negative value, it implies that investors overvalue the association between unrealized income and future performance. If it has significant positive value, it implies that investors undervalue this association.

Additionally, we analyzed hedge portfolio abnormal return ${ }^{8}$ with the following Model that was used in previous research.

$$
\begin{aligned}
& C A R_{t+1}=\beta_{0}+\beta_{1} A C C R_{t}^{H P}+ \\
& +\beta_{2} C F O_{t}+\beta_{3} F V 1^{H P}\left(\text { or } F V 2^{H P}\right)_{t}+ \\
& +\beta_{4} S I Z E_{t}+\beta_{5} M B_{t}+\beta_{6} L E V_{t}+ \\
& +\beta_{7} V O L_{t}+\Sigma Y E A R_{t}+\Sigma I N D_{t}+\varepsilon_{t} .
\end{aligned}
$$

where $A C C R^{H P}$ - scaled-decile ranks for $A C C R$ (samples ranked depending on the size of $A C C R$ from 0 to 9 and ranks divided by 9), $F V 1^{H P}$ scaled-decile ranks for $F V 1$ (samples ranked depending on the size of $F V 1$ from 0 to 9 and ranks divided by 9), $F V 2^{H P}$ - scaled-decile ranks for $F V 2$ (samples ranked depending on the size of $F V 2$ from 0 to 9 and ranks divided by 9 ).

An order from 0 to 9 was given on the basis of initial values of variables, and then those given values were divided by 9 so that the variables could have a value from 0 to 1 . If so, the coefficient of each variable can be interpreted as information about the profit rate of a zero-investment portfolio in which relatively large values mean purchasing, whereas relatively small values mean selling.

Thus, in Model (3), if the coefficient of $F V^{H P}$ has a statistically significant negative value, one can interpret that investors get excess returns with the overvaluation of fair value.

\subsection{Data and sample selection}

In terms of interest variables, this study analyzes firms listed on the Korea Stock Exchange market from 2011 to 2012. The financial industry, companies whose fiscal year-end month is not December, administrated firms, and companies under impairment of capital were excluded from this research for the following reasons. The comparison between the financial statements of first cases is not easy. We excluded the second cases in order to control the influence of fiscal year-end month on the stock price. The third and last cases were excluded because those are expected to cause bias in the research results. Additionally, excluding companies that do not provide sufficient financial data or data about fair value gains and losses, the total samples are 944 companies.

The sample selection methods used in this research are described in Table 1.

The financial data studied in this research were collected from Data Guide Pro provided by Fn-Guide.

8 Standardized deciles were used to analyze the hedge portfolio interest rate. This method was suggested by Rajgopal, Shevlin, and Venkatachalam (2003) and Abarbanell and Bushee (1998). See Appendix about the detailed portfolio. 
Table 1. Sample selection

\begin{tabular}{|c|c|}
\hline Sample selection process & Number of firm-year observations \\
\hline Total sample 2011-2012 & 1,451 \\
\hline Less: firms with non-December 31 fiscal year-end & 46 \\
\hline Less: financial institutions & 102 \\
\hline Less: firms without necessary financial data & 54 \\
\hline Less: firms without financial instruments fair value data & 251 \\
\hline Total sample & 944 \\
\hline
\end{tabular}

\section{RESULTS}

\subsection{Descriptive statistics and correlation analysis}

Table 2 shows the means, medians, standard deviations, maximums, and minimums of the main variables ${ }^{9}$ used in the verification of the hypothesis.

Table 2. Descriptive statistics

\begin{tabular}{l|c|c|c|c|c}
\hline \multicolumn{7}{c}{$N=\mathbf{9 4 4}$} \\
\hline Variables & Mean & Median & Std. & Min & Max \\
\hline$E A R \_N I$ & 0.021 & 0.027 & 0.071 & -0.269 & 0.201 \\
CAR & -0.020 & -0.059 & 0.502 & -1.930 & 6.741 \\
$F V 1$ & 0.017 & 0.000 & 0.059 & -0.043 & 0.358 \\
$F V 2$ & 0.014 & 0.000 & 0.060 & -0.089 & 0.357 \\
$A C C R$ & -0.008 & -0.006 & 0.076 & -0.317 & 0.194 \\
$C F O$ & 0.042 & 0.037 & 0.077 & -0.162 & 0.254 \\
$S I Z E$ & 19.888 & 19.675 & 1.622 & 16.509 & 24.207 \\
MB & 1.132 & 0.788 & 1.056 & 0.143 & 6.290 \\
\hline$L E V$ & 1.202 & 0.853 & 1.298 & 0.045 & 9.100 \\
VOL & 0.441 & 0.419 & 0.151 & 0.165 & 0.964 \\
\hline
\end{tabular}

Note: EAR_NI - net income divided by average assets, CAR size-adjusted abnormal returns accumulated over 12 months from April 1 in year $t+1$ to March in year $t+2, F V 1-$ fair value gain and loss of financial instruments divided by average assets, FV2 - fair value gain and loss excluding impairment loss of financial instruments divided by average assets, $A C C R$ - (net income-operating cash flow - unrealized gain and loss from fair value measurement of financial instruments)/ average assets, $C F O$ - operating cash flow divided by average assets, SIZE - natural log of total sales, $M B$ - market value divided by book value, $L E V$ - total liabilities divided by total equity, $V O L$ - standard deviation of daily stock return.

The mean and the median of EAR_NI, a main dependent variable, were 0.021 and 0.027 respectively; those of $A C C R$, a control variable, were -0.008 and -0.006 respectively; and those of $C F O$, a control variable, were 0.042 and 0.037 , respective- ly. These results are similar to those of previous studies.

Concerning the verification of the hypothesis, the mean and the median of $C A R$, a dependent variable, were -0.020 and -0.059 . These results have a similar distribution as Jang et al. (2008) who measured profit rate with the same method.

The medians for $F V 1$ and $F V 2^{10}$, interest variables, were calculated as 0.017 and 0.014 , respectively. The reason why the value of the latter is smaller than that of former is because the impairment loss was subtracted from $F V 1$ and the reversal of the impairment loss was added to it. It implies that companies recognize about $1.7 \%$ of the average assets as fair value gains and losses. It is interpreted that the influence of fair value measurement is considerable, considering that it is about $2 \%$ for $E A R \_N I$.

Additionally, it was identified that the distributions of other control variables, such as SIZE, $M B$, $L E V$ and $V O L$, were similar to those of previous research.

Table 3 shows the Pearson correlations used in the verifications of the hypothesis.

$F V 1$ and $F V 2$, interest variables, had significant positive associations with EAR_NI at 5\% or $1 \%$ significance level. These results imply that fair value measurement has predictability for future performance. ACCR and CFO, control variables, had a significant association with $C A R$, the dependent variable. These results were the same as previous studies.

9 In order to control the influences of outliers of each variable, the extreme values that fell into the top and bottom $1 \%$ were winsorized.

10 In this paper, the accumulated amount of fair value gains and losses for financial instruments is defined as FV1 and FV2. According to Evans et al. (2014), the predictability to future performance can be analyzed through the accumulated amount of fair value gains and losses in a comprehensive income statement rather than the net income in the statement of comprehensive income, because the former is replaced for realized earnings. 
Table 3. Correlation matrix

\begin{tabular}{|c|c|c|c|c|c|c|c|c|c|}
\hline \multicolumn{10}{|c|}{$N=944$} \\
\hline Variable & CAR & ACCR & CFO & FV1 & FV2 & SIZE & MB & LEV & VOL \\
\hline$E A R$ & 0.228 & 0.128 & 0.434 & 0.078 & 0.093 & 0.133 & 0.284 & -0.393 & -0.249 \\
\hline $\mathrm{NI}$ & $<.0001$ & $<.0001$ & $<.0001$ & 0.017 & 0.004 & $<.0001$ & $<.0001$ & $<.0001$ & $<.0001$ \\
\hline \multirow{2}{*}{$C A R$} & 1.000 & -0.080 & 0.108 & -0.048 & -0.045 & -0.146 & -0.050 & -0.172 & -0.162 \\
\hline & - & 0.014 & 0.001 & 0.138 & 0.167 & $<.0001$ & 0.124 & $<.0001$ & $<.0001$ \\
\hline \multirow{2}{*}{$A C C R$} & \multirow{2}{*}{ - } & \multirow{2}{*}{1.000} & -0.591 & 0.044 & 0.056 & 0.012 & 0.018 & -0.240 & -0.079 \\
\hline & & & $<.0001$ & 0.180 & 0.086 & 0.706 & 0.588 & $<.0001$ & 0.015 \\
\hline \multirow{2}{*}{ CFO } & \multirow{2}{*}{ - } & \multirow{2}{*}{-} & \multirow{2}{*}{1.000} & -0.015 & -0.006 & 0.152 & 0.248 & -0.202 & -0.152 \\
\hline & & & & 0.638 & 0.857 & $<.0001$ & $<.0001$ & $<.0001$ & $<.0001$ \\
\hline \multirow{2}{*}{$F V 1$} & \multirow{2}{*}{ - } & \multirow{2}{*}{ - } & \multirow{2}{*}{ - } & \multirow{2}{*}{1.000} & 0.985 & 0.067 & -0.048 & -0.100 & -0.089 \\
\hline & & & & & $<.0001$ & 0.039 & 0.142 & 0.002 & 0.006 \\
\hline \multirow{2}{*}{ FV2 } & \multirow{2}{*}{-} & \multirow{2}{*}{-} & \multirow{2}{*}{ - } & \multirow{2}{*}{ - } & \multirow{2}{*}{1.000} & 0.082 & -0.047 & -0.110 & -0.107 \\
\hline & & & & & & $<.0001$ & $<.0001$ & $<.0001$ & $<.0001$ \\
\hline \multirow{2}{*}{ SIZE } & \multirow{2}{*}{-} & \multirow{2}{*}{-} & \multirow{2}{*}{-} & \multirow{2}{*}{-} & \multirow{2}{*}{-} & \multirow{2}{*}{1.000} & 0.249 & 0.222 & -0.164 \\
\hline & & & & & & & $<.0001$ & $<.0001$ & $<.0001$ \\
\hline \multirow{2}{*}{$M B$} & \multirow{2}{*}{-} & \multirow{2}{*}{-} & \multirow{2}{*}{ - } & \multirow{2}{*}{-} & \multirow{2}{*}{-} & \multirow{2}{*}{-} & 1.000 & 0.119 & 0.125 \\
\hline & & & & & & & 1.000 & 0.000 & 0.000 \\
\hline LEV & _- & _- & _- & _- & - & - & - & 1000 & 0.275 \\
\hline & & & & & & & & & $<.0001$ \\
\hline VOL & - & - & - & - & - & - & - & - & 1 \\
\hline
\end{tabular}

Notes: $P$-values are in parentheses. The definitions of variables are presented in Table 2.

\subsection{Empirical results}

Table 4 shows the results of the verification of the hypothesis. In particular, this table includes the differences between the predictabilities observed through accounting information and those expected by investors.

$$
\begin{aligned}
& E A R_{-} N I_{t+1}=\beta_{0}+\beta_{1} A C C R_{t}+\beta_{2} C F O_{t}+ \\
& +\beta_{3} F V 1(\text { or } F V 2)_{t}+\beta_{4} S I Z E_{t}+\beta_{5} M B_{t}+ \\
& +\beta_{6} L E V_{t}+\beta_{7} V O L_{t}+\Sigma Y E A R_{t}+\Sigma I N D_{t}+\varepsilon_{t} . \\
& C A R_{t+1}=\beta_{0}+\beta_{1} A C C R_{t}+\beta_{2} C F O_{t}+ \\
& +\beta_{3} F V 1(\text { or } F V 2)_{t}+\beta_{4} S_{Z I}+\beta_{5} M B_{t}+ \\
& +\beta_{6} L E V_{t}+\beta_{7} V O L_{t}+\Sigma Y E A R_{t}+\Sigma I N D_{t}+\varepsilon_{t} . \\
& C A R_{t+1}=\beta_{0}+\beta_{1} A C C R_{t}^{H P}+\beta_{2} C F O_{t}+ \\
& +\beta_{3} F V 1^{H P}\left(\text { or } F V 2^{H P}\right)_{t}+\beta_{4} S_{Z I Z E_{t}}+\beta_{5} M B_{t}+ \\
& +\beta_{6} L E V_{t}+\beta_{7} V O L_{t}+\Sigma Y E A R_{t}+\Sigma I N D_{t}+\varepsilon_{t} .
\end{aligned}
$$

In Model (1), we identified if there is the predictability of $F V 1$ (or $F V 2$ ) for future performance
(EAR_NI) observed through accounting information. With Model (2), we analyze whether investors over-expect (or under-expect) predictability compared to the observed one; with Model (3), we analyze whether investors can get excess returns by using over-expectation (or under-expectation).

In Model (1), it is identified that fair value has a predictability observed in accounting information, because $F V$ had significant positive value. In Model (2), the regression coefficient of $F V$ had significant negative value at $1 \%$ significance level. This implies that investors overvalue fair value compared to predictability based on accounting information, as they do for accruals ${ }^{11}$. Though the fair value gains and losses are unrealized, investors tend to expect that it would be larger than the predictability observed in the way of accounting. As in the case of accruals, the functional fixation is judged as to be the reason. That is, although the predictability of FV observed in accounting is smaller than $A C C R^{12}$, because realized and unrealized accruals are not evaluated separately, investors tend not to recognize it. Additionally, investors' overvaluation can be derived from its weak

11 The overvaluation of accruals was found by Sloan (1996), and he calls it "accrual anomaly". The same phenomenon is also found in Korea.

12 In Model (1), the regression coefficients of ACCR and FV1 are 0.400 and 0.061 , respectively, and the results of an F-test show that the former is significantly larger than the latter. It means that ACCR is larger than FV in the predictability observed in the way of accounting. 
Table 4. Predictability and pricing of fair value for future performance

\begin{tabular}{|c|c|c|c|c|c|c|}
\hline \multirow{2}{*}{ Variable } & \multicolumn{3}{|c|}{ Independent variable $F V 1$} & \multicolumn{3}{|c|}{ Independent variable $F V 2$} \\
\hline & Model (1) & Model (2) & Model (3) & Model (1) & Model (2) & Model (3) \\
\hline \multirow{2}{*}{ Intercept } & 0.004 & 1.117 & 0.966 & 0.005 & 1.113 & 0.958 \\
\hline & $(0.17)$ & $(4.02)^{* * *}$ & $(4.88)^{* * *}$ & $(0.19)$ & $(4.02)^{* * *}$ & $(4.85)^{* * *}$ \\
\hline \multirow{2}{*}{$A C C R_{t}$} & 0.400 & -0.810 & -0.111 & 0.399 & -0.799 & -0.925 \\
\hline & $(7.45)^{* * *}$ & $(-1.95)^{*}$ & $(-1.88)^{*}$ & $(7.44)^{* * *}$ & $(-1.93)^{*}$ & $(-1.74)^{*}$ \\
\hline \multirow[b]{2}{*}{$\mathrm{CFO}_{t}$} & 0.555 & -0.059 & 0.259 & 0.554 & -0.049 & 0.282 \\
\hline & $(13.13)^{* * *}$ & $(-0.15)$ & $(0.97)$ & $(13.10)^{* * *}$ & $(-0.13)$ & $(1.06)$ \\
\hline \multirow{2}{*}{$F V 1($ or FV2) } & 0.061 & -0.543 & -0.091 & 0.059 & -0.508 & -0.081 \\
\hline & $(2.84)^{* * * *}$ & $(-3.20)^{* * *}$ & $(-2.30)^{* *}$ & $(2.77)^{* * *}$ & $(-3.00)^{* * *}$ & $(-1.96)^{*}$ \\
\hline \multirow{2}{*}{$S I Z E_{t}$} & 0.001 & -0.045 & -0.034 & 0.001 & -0.045 & -0.034 \\
\hline & $(1.05)$ & $(-3.59)^{* * *}$ & $(-3.77)^{* * *}$ & $(1.03)$ & $(-3.59)^{* * *}$ & $(-3.78)^{* * *}$ \\
\hline \multirow[b]{2}{*}{$M B_{t}$} & 0.009 & 0.004 & -0.001 & 0.009 & 0.004 & -0.002 \\
\hline & $(4.39)^{* * *}$ & $(0.24)$ & $(-0.09)$ & $(4.39)^{* * *}$ & $(0.24)$ & $(-0.13)$ \\
\hline \multirow{2}{*}{$L E V_{t}$} & -0.006 & -0.041 & -0.034 & -0.006 & -0.041 & -0.033 \\
\hline & $(-2.54)^{* *}$ & $(-2.16)^{* *}$ & $(-2.76)^{* * *}$ & $(-2.56)^{* *}$ & $(-2.15)^{* *}$ & $(-2.69)^{* * *}$ \\
\hline \multirow{2}{*}{$V O L_{t}$} & -0.044 & -0.524 & -0.455 & -0.043 & -0.526 & -0.457 \\
\hline & $(-2.57)^{* *}$ & $(-3.82)^{* * *}$ & $(-3.95)^{* * *}$ & $(-2.55)^{* *}$ & $(-3.83)^{* * *}$ & $(-3.99)^{* * *}$ \\
\hline Year fixed effects & Included & Included & Included & Included & Included & Included \\
\hline Industry fixed effects & Included & Included & Included & Included & Included & Included \\
\hline Adjusted $R^{2}$ & $46.04 \%$ & $8.42 \%$ & $10.45 \%$ & $46.21 \%$ & $8.38 \%$ & $10.34 \%$ \\
\hline Sample & 944 & 944 & 944 & 944 & 944 & 944 \\
\hline
\end{tabular}

Notes: ${ }^{* *},{ }^{* *}$, and ${ }^{\star}$ denote significance at the 1 percent, 5 percent, and 10 percent level, respectively, based on a two-tail test and robust standard errors adjusted for clustering by firm (Petersen, 2009). Variable definitions are presented in Table 2.

reliability, as Richardson et al. (2005) argue, and it can also be derived from low convertibility.

Concerning the control variable $C F O$, Sloan (1996) reports the results of undervaluation. However, it is not significant in Korea, as this research shows. Regarding ACCR, both domestic and foreign studies report the results of overvaluation, as the present study shows.

Next, with Model (2), we analyzed whether investors can get excess returns due to their overvaluation.

The results show that the regression coefficient of $F V 1^{H P}$ had significant negative value at the $5 \%$ sig- nificance level. The directions must be interpreted as opposite, because we constructed a hedge portfolio as a long position for that with a larger FV and short position for that with smaller $F V$. We interpret that investors get positive excess returns by the short position for the overvalued portfolio due to its larger $F V$ and the long position for the undervalued one due to its smaller $F V$, because investors overvalue the predictability of $F V s^{13}$. The results of other control variables are similar to those of the previous studies.

In conclusion, these results support the hypothesis that investors evaluate the predictability of fair value gains and losses differently from that observed in the way of accounting.

\section{CONCLUSION}

The application of the fair value accounting keeps expanding in order to achieve the purpose of financial accounting, the provision of useful information in the prediction of future performance. Since 2011, when IFRS were introduced in Korea, most accounts in the statement of financial position are required

13 Previous research evaluated the profit rate of a hedge portfolio according to the size of accrual in the same way. Specifically, the results of regression analysis for focal variables indicate that their regression coefficients are significant negative values, and then interpreted those as the occurrence of an excess return rate. 
to evaluate their fair values mandatorily or selectively. We identified capital market investors' perception of fair value-based valuation, comparing between the predictability of fair value in the accounting performance and the value perceived by market investors.

The results of the analysis reveal that investors tend to overvalue fair value more than predictive values reflected in accounting performance. In particular, the results show that investors can gain abnormal returns through the market anomaly due to the functional fixation that investors cannot distinguish between unrealized profits and realized ones.

Concerning accruals, researchers have traditionally concentrated on the its recognition level by investors and its usefulness. However, research that explores it with the distinction of accruals into unrealized profits and realized ones has hardly been conducted. In the new accounting circumstances, the part recognized as unrealized gains and losses would be expanded. Furthermore, revised accounting standards mandate companies to report their comprehensive income statements, which are composed of only unrealized gains and losses, as the main component of the financial statements. With the result that investors tend to overvalue unrealized earnings, we suggest that information about unrealized earnings should be reported separately.

\section{ACKNOWLEDGMENT}

This paper was modified and developed from the Ph.D. thesis of the first author.This study was supported by the research grant of Incheon National University in 2016.

\section{REFERENCES}

1. Abarbanell, J., \& Bushee, B. (1998). Abnormal returns to a fundamental analysis strategy. The Accounting Review, 73(1), 19-45. Retrieved from https://papers.ssrn. com/sol3/papers.cfm?abstract_ $\mathrm{id}=40740$

2. Aboody, D., Barth, M. E., \& Kasznik, R. (1999). Revaluation of fixed assets and future firm performance: Evidence from the UK. Journal of Accounting and Economics, 26(1-3), 149-178. https://doi.org/10.1016/s01654101(98)00040-8

3. Allen, F., \& Carletti, E. (2008). Mark-to-market accounting and liquidity pricing. Journal of Accounting and Economics, 45(2-3), 358-378. https://doi.org/10.1016/j. jacceco.2007.02.005

4. Barth, M. E. (1991). Relative measurement errors among alternative pension asset and liability measures. The Accounting Review, 66(3), 433-463. Retrieved from https://www.gsb.stanford. edu/faculty-research/publications/ relative-measurement-errorsamong-alternative-pension-assetliability

5. Barth, M. E. (1994). Fair value accounting: Evidence from investment securities and the market valuation of banks. The Accounting Review, 69(1), 1-25. Retrieved from https://www.gsb. stanford.edu/faculty-research/ publications/fair-value-accounting-evidence-investment-securities-market-valuation

6. Barth, M. E., Beaver, W. H., \& Landsman, W. R. (1996). Value relevance of banks fair value disclosures under SFAS 107. The Accounting Review, 71(4), 513-537. Retrieved from https://www.jstor. org/stable/248569? seq=1\#page_ scan_tab_contents

7. Barth, M. E., \& Clinch, G. (1998). Revalued financial, tangible and intangible assets: associations with share prices and non-marketbased value estimates. Journal of Accounting Research, 36, 199-233. https://doi.org/10.2307/2491314
8. Barth, M. E., \& Landsman, W. R. (2010). How did Financial Reporting Contribute to the Financial Crisis? European Accounting Review, 19(3), 399-423. https://doi.org/10.1080/09638180.2 010.498619

9. Bernard, V., \& Ruland, R. (1987) The incremental information content of historical costs and current cost number: Time series analysis. The Accounting Review, 62(4), 707-722. Retrieved from https://www.jstor.org/stable/ pdf/247780.pdf?seq=1\#page_scan_ tab_contents

10. Chan, K., Chan, L. C., Jegadeesh, N., \& Lakonishok, J. (2006). Earnings quality and stock returns. Journal of Business, 79(3), 1041-1082. https://doi. org/10.1086/500669

11. Chen, X., \& Cheng, Q. (2002). Abnormal accrual-based anomaly and managers' motivation to abnormal accruals (Working paper). University of Chicago. https://doi. org/10.2139/ssrn.309843 
12. Dechow, P. M., Myers, L. A., \& Shakespeare, C. (2010). Fair value accounting and gains from asset securitizations: A convenient earnings management tool with compensation sidebenefits. Journal of Accounting and Economics, 49(1-2), 2-25. https://doi.org/10.1016/j.jacceco.2009.09.006

13. Easton, P. D., Eddey, P. H., \& Harris, T. S. (1993). An investigation of revaluations of tangible long-lived assets. Journal of Accounting Research, 31, 1-38. https://doi.org/10.2307/2491161

14. Evans, M., Hodder, L., \& Hopkins, P. E. (2014). The Predictive Ability of Fair Values for Future Financial Performance of Commercial Banks and the Relation of Predictive Ability to Banks' Share Prices. Contemporary Accounting Research, 31(1), 13-44. https://doi. org/10.1111/1911-3846.12028

15. Financial Accounting Standards Board (2010). Chapter 1, The objective of general purpose financial reporting, and Chapter 3, Qualitative characteristics of useful financial information. (Statement of Financial Accounting Concepts No. 8). Norwalk, CT: FASB. Retrieved from https://www.fasb. org/jsp/FASB/Page/SectionPage\&c $\mathrm{id}=1176156316498 \# 2010$

16. Hilton, A. S., \& O'Brien, P. C. (2009). Inco Ltd.: Market Value, Fair Value, and Management Discretion. Journal of Accounting Research, 47(1), 179-211. https://doi.org/10.1111/j.1475679x.2008.00314.x

17. Hodder, L., Hopkins, P., \& Wahlen, J. (2006). Risk-relevance of fair value income measures for commercial banks. The Accounting Review, 81(2), 337-375. https://doi. org/10.2308/accr.2006.81.2.337

18. Kraft, A., Leon, A. J., \& Wasley, C. E. (2007). Regression-based tests of the market pricing of accounting numbers: The Mishkin test and ordinary least squares. Journal of Accounting Research, 45(5), 1081-1114. https://doi.org/10.1111/j.1475679x.2007.00261.x

19. Landsman, W. R., Miller, B. L., Peasnell, K., \& Yeh, S. (2011). Do Investors Understand Really Dirty Surplus? The Accounting Review, 86(1), 237-258. https://doi. org/10.2308/accr.00000014

20. Mishkin, F. S. (1983). Rational Expectations Approach to Macroeconometrics: Testing Policy Effectiveness and Efficient-markets Models. Chicago, IL: University of Chicago Press. Retrieved from http://www.nber.org/books/ mish83-1

21. Park, M. S., Park, T., \& Ro, B. T. (1999). Fair value disclosures for investment securities and bank equity: evidence from SFAS 115. Journal of Accounting, Auditing and Finance, 14(3), 347-370. https://doi. org/10.1177/0148558x9901400311

22. Peterson, M. (2011). Estimating standard errors in finance panel data sets: Comparing approaches. Review of Financial Studies, 22(1), 435-480. https://doi.org/10.1093/ rfs/hhn053

23. Petroni, K. R., \& Wahlen, J. M. (1995). Fair Values of Equity and
Debt Securities and Share Prices of Property-Liability Insurers. Journal of Risk and Insurance, 62(4), 719-737. https://doi. org/10.2307/253592

24. Rajgopal, S., Shevlin, T., \& Venkatachalam, M. (2003). Does the stock market fully appreciate the implications of leading indicators for future earnings? Evidence from order backlog. Review of Accounting Studies, 8(4), 461-492. https://doi. org/10.1023/a:1027364031775

25. Richardson, S. A., Sloan, R. G., Soliman, M. T., \& Tuna, A. I. (2005). Accrual reliability, earnings persistence and stock prices. Journal of Accounting and Economics, 39(3), 437-485. https://doi.org/10.1016/j.jacceco.2005.04.005

26. Sloan, R. (1996). Do stock prices fully reflect information in accruals and cash flows about future earnings? The Accounting Review, 71(3), 289-315. Retrieved from https://www.researchgate net/publication/279888468 Do_Stock_Prices_Fully_Reflect_Information_in_Accruals_and_Cash_Flows_About_Future_Earnings

27. Thomas, J. K., \& Zhang, H. (2002). Inventory changes and future returns. Review of Accounting Studies, 7(2/3), 163-187. https:// doi.org/10.1023/a:1020221918065

28. Xie, H. (2001, July). The mispricing of abnormal accruals. The Accounting Review, 76, 357373. https://doi.org/10.2308/ accr.2001.76.3.357 


\section{APPENDIX}

\section{Fair value (FV) hedge portfolio}

The concept of a hedge portfolio is constructed in the distinction of 10 sub-samples pending of FV value for each year. The hedge portfolio is constructed as a long position for that with larger FV and short position for that with smaller FV.

\begin{tabular}{|c|c|c|c|c|}
\hline No. & Sub-samples & Year t & $t+1$ & $(\mathrm{X}-\mathrm{XMEAN})$ \\
\hline 1 & $10 \%$ firm sample (the largest FV) & long 1 & Long 1 & $1-4.5 / 9=4.5 / 9$ \\
\hline 2 & $10 \%$ firm sample ((the second largest FV) & long $8 / 9$ & long $8 / 9$ & $8 / 9-4.5 / 9=3.5 / 9$ \\
\hline 3 & $10 \%$ firm sample & long $7 / 9$ & long $7 / 9$ & $7 / 9-4.5 / 9=2.5 / 9$ \\
\hline 4 & $10 \%$ firm sample & long 6/9 & long $6 / 9$ & $6 / 9-4.5 / 9=1.5 / 9$ \\
\hline 5 & $10 \%$ firm sample & long $5 / 9$ & long $5 / 9$ & $5 / 9-4.5 / 9=0.5 / 9$ \\
\hline 6 & $10 \%$ firm sample & short $4 / 9$ & short $4 / 9$ & $4 / 9-4.5 / 9=-0.5 / 9$ \\
\hline 7 & $10 \%$ firm sample & short $3 / 9$ & short $3 / 9$ & $3 / 9-4.5 / 9=-1.5 / 9$ \\
\hline 8 & $10 \%$ firm sample & short $2 / 9$ & short $2 / 9$ & $2 / 9-4.5 / 9=-2.5 / 9$ \\
\hline 9 & $10 \%$ firm sample & short $1 / 9$ & short $1 / 9$ & $1 / 9-4.5 / 9=-3.5 / 9$ \\
\hline 10 & $10 \%$ firm sample (the smallest FV) & short 0 & short 0 & $0 / 9-4.5 / 9=-4.5 / 9$ \\
\hline
\end{tabular}

